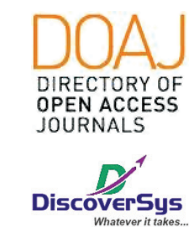

Published by DiscoverSys

\title{
Gambaran evaluasi tingkat nyeri pasien pasca operasi radang usus buntu dengan bedah terbuka dan laparoskopi di Rumah Sakit Umum Pusat Sanglah Denpasar tahun 2016
}

\author{
Dewa Ayu Wahyu Diantari, ${ }^{*}{ }^{*}$ IGL Ngr Agung Artha Wiguna, ${ }^{2}$ I Wayan Niryana ${ }^{2}$
}

\section{ABSTRACT}

Appendicitis is an inflammation of the vermiform appendix. Postoperative patients of appendicitis treated by open surgery or laparoscopy, will feel a pain sensation of the surgery performed.

Aim: To determine the evaluated pain level in general overview and based on the characteristics of the data.

Method: This study observes postoperative patients doing open surgery and laparoscopy at the Sanglah General Hospital Denpasar in 2016, from first day until third day of post-surgery. It was observational retrospective study by evaluating VAS (visual analogic scale) which had been listed in the patient's medical record.
Result: 44 patients with open surgery showed that the pain level recorded in first day were $75 \%$ of mild pain and $25 \%$ of moderate pain. In second day, it was $2.3 \%$ of no pain, $86.4 \%$ of moderate pain, and $11.4 \%$ of severe pain. At least, it's been $1 \%$ of no pain, $88.6 \%$ of mild pain, and $2.3 \%$ of moderate pain. In other hand, there were 6 patients with laparoscopic surgery showed that both no pain and mild pain was $50 \%$, respectively, found in the first day. In second day. It was $66.7 \%$ of no pain and $33.3 \%$ of mild pain. The last day, it's been $83.3 \%$ of no pain and $16.7 \%$ of mild pain. Summary: Most of pain level in post open surgical patients with appendicitis is in mild pain level and so laparoscopic surgery is in no pain level.

Keywords: pain, appendicitis, VAS (visual analog scale)

Cite This Article: Diantari, D.A.W., Wiguna, I.G.L.N.A.A., Niryana, I.W. 2018. Gambaran evaluasi tingkat nyeri pasien pasca operasi radang usus buntu dengan bedah terbuka dan laparoskopi di Rumah Sakit Umum Pusat Sanglah Denpasar tahun 2016. Intisari Sains Medis 9(2): 100-106. DOI: 10.1556/ism.v9i2.158

\section{ABSTRAK}

Radang pada usus buntu merupakan peradangan dari apendiks vermiformis. Pasien pasca operasi radang usus buntu yang ditangani dengan bedah terbuka atau laparoskopi akan merasakan suatu sensasi nyeri dari tindakan pembedahan yang dilakukan.

Tujuan: Mengetahui gambaran evaluasi tingkat nyeri secara umum dan berdasarkan karakteristik data sampel.

Metode: Penelitian ini menggunakan desain retrospektif observasional. Sampel ialah pasien pasca operasi radang usus buntu dengan bedah terbuka dan laparoskopi di Rumah Sakit Umum Pusat Sanglah Denpasar dari tahun 2016 dari hari pertama hingga hari ketiga pasca operasi. Pengambilan data menggunakan data sekunder, meliputi: skor VAS (visual analog scale) yang telah tertera pada rekam medis pasien. Tingkat nyeri dilihat dari hari pertama hingga hari ketiga pasien pasca operasi radang usus buntu dengan bedah terbuka dan laparoskopi.

Hasil: Terdapat sebanyak 44 orang pasien bedah terbuka memberikan gambaran tingkat nyeri yang terdata pada hari pertama $75 \%$ nyeri ringan dan $25 \%$ nyeri sedang, hari kedua 2,3\% tanpa nyeri, $86,4 \%$ nyeri sedang, dan 11,4 nyeri berat, serta pada hari ketiga 9,1\% tanpa nyeri, 88,6 nyeri ringan, 2,3\% nyeri sedang. Terdapat pula 6 orang pasien dengan laparoskopi yang terdata pada hari pertama 50\% tanpa nyeri dan 50\% nyeri ringan, pada hari kedua $66,7 \%$ tanpa nyeri dan $33,3 \%$ nyeri ringan, serta pada hari ketiga $83,3 \%$ tanpa nyeri dan $16,7 \%$ nyeri ringan.

Simpulan: Gambaran evaluasi tingkat nyeri pasien pasca operasi radang usus buntu dengan bedah terbuka adalah nyeri ringan, sedangkan untuk laparoskopi adalah tanpa nyeri.
${ }^{2}$ SMF/Bagian IImu Bedah Rumah Sakit Umum Pusat Sanglah/ Fakultas Kedokteran Universitas Udayana

\section{*Correspondence to:} Dewa Ayu Wahyu Diantari, Program Studi Pendidikan Dokter, Fakultas Kedokteran, Universitas Udayana wahyudiantari96@gmail.com

Kata kuci: nyeri, radang usus buntu, VAS (visual analog scale)

Cite Pasal Ini: Diantari, D.A.W., Wiguna, I.G.L.N.A.A., Niryana, I.W. 2018. Gambaran evaluasi tingkat nyeri pasien pasca operasi radang usus buntu dengan bedah terbuka dan laparoskopi di Rumah Sakit Umum Pusat Sanglah Denpasar tahun 2016. Intisari Sains Medis 9(2): 100-106. DOI: $10.1556 /$ ism.v9i2.158

\section{PENDAHULUAN}

Peradangan pada usus buntu merupakan salah satu penyakit inflamasi (peradangan) pada sistem pencernaan yang umumnya merupakan suatu tindakan kegawat daruratan, radang usus buntu 
adalah peradangan akut pada apendiks vermiformis. ${ }^{1}$ Insiden terjadinya radang usus buntu akut di negara maju lebih tinggi dibandingkan dengan negara berkembang. ${ }^{2}$ Kejadian radang usus buntu di Amerika Serikat merupakan kedaruratan bedah abdomen yang paling sering dilakukan, dengan jumlah penderita pada tahun 2008 sebanyak 734.138 orang dan meningkat pada tahun 2009 menjadi 739.177. ${ }^{2}$ Peradangan usus buntu di Indonesia berada pada urutan keempat terbanyak pada tahun 2006. Departemen Kesehatan Republik Indonesia pada tahun 2008 merilis data bahwa jumlah penderita radang usus buntu di Indonesia mencapai 591.819 orang dan tahun 2009 terjadi peningkatan sebesar 596.132 orang. Kelompok usia yang umumnya mengalami radang usus buntu yaitu pada usia antara 10-30 tahun, dimana insiden laki-laki lebih tinggi daripada perempuan. ${ }^{3}$

Pada penelitian yang dilakukan di Amerika Serikat pada tahun 2007, dihasilkan data 4 dari 10000 anak usia dibawah 14 tahun menderita radang usus buntu dan lebih dari 80.000 kasus radang usus buntu terjadi di Amerika serikat dalam setahun. WHO memperkirakan insiden radang usus buntu di dunia tahun 2007 mecapai 7\% dari keseluruhan jumlah penduduk dunia. Dari segi usia, usia 20-30 tahun merupakan usia yang paling sering mengalami radang usus buntu. ${ }^{2}$ Apendiktomi (pembedahan untuk mengangkat apendiks) harus dilakukan sesegera mungkin untuk mengurangi risiko perforasi. ${ }^{4}$ Tindakan pembedahan ini akan menimbulkan rasa nyeri pada pasien pasca operasi radang usus buntu

Seiring perkembangan ilmu teknologi kedokteran, teknik pembedahan pada penyakit radang usus buntu bisa dilakukan dengan bedah terbuka atau laparoskopi. Bedah terbuka merupakan teknik pembedahan dengan insisi sepanjang 2-3 inci $(7.6 \mathrm{~cm})$ pada kuadran kanan bawah (Davis-Rockey) atau insisi oblik (McArthur-McBurney), sedangkan laparoskopi adalah pembedahan invansif minimal (tindakan dengan membuat sayatan kecil) yang memerlukan bantuan kamera, monitor dan instrumen-instrumen khusus melakukan pembedahan melalui layar monitor.

Nyeri adalah pengalaman sensori dan emosional yang tidak menyenangkan akibat dari kerusakan jaringan yang aktual atau potensil. ${ }^{4}$ Berdasarkan waktunya nyeri terbagi atas nyeri akut dan nyeri kronis. Nyeri yang terjadi pasca operasi masuk pada katogori nyeri akut, dimana nyeri ini terjadi setelah cedera akut atau intervensi bedah dan berlangsung dalam waktu yang singkat. Nyeri memiliki tingkatan derajatnya dari tidak ada sensai nyeri hingga nyeri berat. Adapun beberapa cara untuk melakukan pengukuran tingkat nyeri, antara lain dengan Numerical Rating Scale (NRS), Visual DescriptifScale (VDS), Visual Analogue Scale (VAS), dan Wong-Baker FACES Pain Rating Scale. Visual Analogue Scale (VAS) merupakan alat pengukuran intensitas nyeri yang memiliki efisiensi yang telah digunakan dalam penelitian dan pengaturan klinis. ${ }^{5}$ VAS umumnya disajikan dalam bentuk garis horisontal. Dalam perkembangannya VAS menyerupai Numerical Rating Scale (NRS) yang cara penyajiannya diberikan angka 0-10 yang masing-masing nomor menunjukan intensitas nyeri yang dirasakan pasien. Pada beberapa penelitian yang dilakukan untuk menilai intensitas nyeri pasca operasi, skala yang digunakan adalah rekombinasi antar VAS dan NRS. ${ }^{6}$

Penanganan pasien radang usus buntu secara operatif khususnya di Rumah Sakit Umum Pusat Sanglah Denpasar memiliki dua pilihan teknik operasi pembedahan yaitu dengan bedah terbuka dan laparoskopi, dimana penanganan operatif radang usus buntu dengan bedah terbuka dan laparoskopi memiliki teknik yang berbeda dalam pengerjaannya. Pasien pasca operasi radang usus buntu baik dengan operasi terbuka ataupun laparoskopi akan merasakan sensasi nyeri pasca operasi, sehigga peneliti mengkaji penelitian untuk mengevaluasi tingkat nyeri pada pasien pasca operasi radang usus buntu dengan bedah terbuka dan laparoskopi yang dilihat dari hari pertama pasca operasi tingga hari ketiga pasca operasi.

\section{METODE}

Penelitian ini menggunakan rancangan deskriptif observasional untuk menjelaskan gambaran evaluasi tingkat nyeri pasien pasca operasi radang usus buntu dengan bedah terbuka dan laparoskopi di RSUP Sanglah Denpasar. Gambaran tingkat nyeri dapat diklasifikasikan berdasarkan tingkatan perolehan skor VAS (Visual Analog Scale) menjadi katagori tidak nyeri, nyeri ringan, nyeri sedang, nyeri berat dan terbagi atas penilaian hari pertama, hari kedua dan hari ketiga. Data yang digunakan bersumber dari data rekam medis pasien pasca operasi radang usus buntu dengan bedah terbuka dan laparoskopi. Penelitian ini menggunakan data karakteristik sosiodemografi pasien (usia dan jenis kelamin). Selama tahun 2016, terdapat 50 pasien dengan radang usus buntu, terbagi atas 46 orang dengan bedah terbuka dan 6 orang dengan laparoskopi. Data karakteristik sosiodemografi, distribusi tingkatan nyeri dari hari pertama hingga hari ketiga pasca operasi radang usus buntu dengan bedah terbuka dan laparoskopi disajikan dalam presentase dan dibandingkan antara kelompok jenis kelamin serta 
usia menggunakan tabulasi silang. Analisis statistik menggunakan bantuan program piranti lunak (software) SPSS ver.2.2.

\section{HASIL}

Karakteristik pasien pasca operasi radang usus buntu dari penelitian yang dilakukan, menyajikan hasil tentang karakteristik demografi data responden. Proporsi karakteristik pasien pasca operasi radang usus buntu dengan bedah terbuka meliputi jenis kelamin dan usia yang secara rinci dapat dilihat pada tabel 1.1. Dari 44 pasien pasca operasi radang usus buntu dengan bedah terbuka, pasien yang berjenis kelamin laki-laki lebih banyak (61.4\%) daripada perempuan (38.6\%), sedangkan usia didominasi oleh pasien dengan rentang usia 13-20 tahun (36.4\%). Karakteristik pasien pasca operasi radang usus buntu dengan laparoskopi dapat dilihat pada tabel 1.2. Dari 6 pasien pasca operasi radang usus buntu dengan laparoskopi, pasien yang berjenis kelamin laki-laki lebih banyak (83.3\%) daripada perempuan (16.7\%), sedangkan faktor usia didominasi oleh pasien yang berusia rentang 13-20 tahun (66.7\%).

\section{Tabel 1.1 Karakteristik Responden Pasien Pasien Pasca Operasi} Radang Usus Buntu dengan Bedah Terbuka

\begin{tabular}{lcc}
\hline $\begin{array}{l}\text { Karakteristik } \\
\text { Responden }\end{array}$ & \multicolumn{2}{c}{$\mathbf{N = 4 4}$ orang } \\
\cline { 2 - 3 } $\begin{array}{l}\text { Jenis Kelamin } \\
\text { Laki -laki }\end{array}$ & Frekuensi (N) & Persentase (\%) \\
Perempuan & 17 & 61.4 \\
Usia & & 38.6 \\
13-20 tahun & 16 & \\
$21-30$ tahun & 10 & 36.4 \\
$31-40$ tahun & 7 & 22.7 \\
$41-50$ tahun & 6 & 15.9 \\
$51-60$ tahun & 5 & 13.6 \\
\end{tabular}

Tabel 1.2 Karakteristik Responden Pasien Pasien Pasca Operasi Radang Usus Buntu dengan Laparoskopi

\begin{tabular}{lcc}
\hline Karakteristik & \multicolumn{2}{c}{$\mathbf{N = 6}$ orang } \\
\cline { 2 - 3 } Responden & Frekuensi (N) & Persentase (\%) \\
\hline Jenis Kelamin & 5 & 83.3 \\
Laki -laki & 1 & 16.7 \\
Perempuan & & \\
Usia & 4 & 66.7 \\
$13-20$ tahun & 0 & 0 \\
$21-30$ tahun & 2 & 33.3 \\
$31-40$ tahun & 0 & 0 \\
$41-50$ tahun & 0 & 0 \\
$51-60$ tahun & & \\
\hline
\end{tabular}

Berdasarkan hasil penelitian ini, tingkat nyeri pada pasien pasca radang usus buntu dengan bedah terbuka di Rumah Sakit Umum Pusat Sanglah Denpasar 2016, diperoleh bahwa terdapat perbedaan proporsi tingkat nyeri pasien pasca operasi radang usus buntu dari hari pertama setelah operasi hingga hari ketiga. Teknik bedah terbuka dengan jumlah sampel data 44 orang terinci pada tabel 1.3, hari pertama terdata lebih banyak tingkat nyeri ringan 33 orang $(75 \%)$ daripada nyeri sedang 11 orang (25\%) dan 0 untuk tidak nyeri. Hari kedua lebih banyak pasien nyeri ringan sebanyak 38 orang $(86.4 \%)$ daripada nyeri sedang 5 orang $(11.4 \%)$ dan 1 orang $(2.3 \%)$ pasien tidak nyeri. Hari ketiga terdata nyeri ringan mendominasi sebanyak 39 orang (88.6\%) sedangkan nyeri sedang 1 orang $(2.3 \%)$ dan 4 orang $(9.1 \%)$ pasien tidak nyeri. Hari pertama hingga hari ketiga pasien pasca operasi tingkat nyeri berat tidak ada (0\%). Pada laparoskopi, jumlah sampel sebanyak 6 orang terinci pada tabel 1.4, hari pertama terdapat sebanyak 3 orang (50\%) pasien tidak nyeri, 3 orang (50\%) pasien nyeri ringan. Hari kedua terdata lebih banyak pasien tidak nyeri 4 orang $(66.7 \%)$ daripada pasien nyeri ringan 2 orang (33.3\%). Hari ketiga terdata sebanyak 5 orang $(83.3 \%)$ pasien tidak nyeri, sedangkan pasien nyeri ringan 1 orang (16.7\%) Pada hari pertama hingga hari ketiga pasien pasca operasi radang usus buntu dengan teknik laparoskopi, tidak didapatkan tanda nyeri sedang dan berat $(0)$.

Berdasarkan jenis kelamin, pasien pasca operasi dengan bedah terbuka di dominasi oleh nyeri ringan pada laki-laki (hari pertama: 66.7\%, hari kedua $77.8 \%$, dan hari ketiga: $81.5 \%$ ) dan perempuan (hari pertama: $88.2 \%$, hari kedua: $100 \%$, dan hari ketiga 100\%) terperinci pada Tabel 1.5. Pada pasien pasca operasi dengan laparoskopi, hari pertama pada laki-laki didominasi oleh nyeri ringan $(60 \%)$ sedangkan perempuan didominasi oleh tidak adanya nyeri (100\%). Pada hari kedua, pasien laki-laki didominasi oleh tidak adanya nyeri (80\%), sedangkan perempuan dengan nyeri ringan (100\%). Terakhir pada hari ketiga didominasi tanpa nyeri pada laki-laki (80\%) dan perempuan (100\%) yang terperinci pada Tabel 1.6.

Berdasarkan usia, pasien pasca operasi dengan bedah terbuka di dominasi oleh nyeri ringan pada rentangan usia 13-20 tahun (hari pertama : 62.5\%, hari kedua: $62.5 \%$, dan hari ketiga: $93.8 \%$ ) yang terperinci pada tabel 1.7. Sedangkan pada pasien pasca operasi dengan laparoskopi di dominasi oleh tidak adanya nyeri pada rentang usia 13-20 tahun (hari pertama: 50\%, hari kedua: $75 \%$, dan hari ketiga: $100 \%)$ yang terperinci pada tabel 1.8 . 
Tabel 1.3 Distribusi Tingkat Nyeri Pasca Operasi Radang Usus Buntu dengan Bedah Terbuka Hari Pertama hingga Hari Ketiga

\begin{tabular}{|c|c|c|c|c|c|c|c|c|c|c|}
\hline \multirow{2}{*}{$\begin{array}{l}\text { Evaluasi Hari Pasca } \\
\text { Operasi }\end{array}$} & \multicolumn{2}{|c|}{ Tidak (0) } & \multicolumn{2}{|c|}{ Nyeri Ringan (1-3) } & \multicolumn{2}{|c|}{ Nyeri Sedang (4-6) } & \multicolumn{2}{|c|}{ Nyeri Berat (7-10) } & \multicolumn{2}{|c|}{ Total } \\
\hline & (N) & (\%) & (N) & $(\%)$ & (N) & (\%) & (N) & (\%) & (N) & $(\%)$ \\
\hline Hari Pertama & 100 & - & 33 & 75.0 & 11 & 25.0 & - & - & 44 & 100 \\
\hline Hari Kedua & 1 & 2,3 & 38 & 86.4 & 5 & 11.4 & - & - & 44 & 100 \\
\hline Hari Ketiga & 4 & 9,1 & 39 & 88.6 & 1 & 2.3 & - & - & 44 & 100 \\
\hline
\end{tabular}

Tabel 1.4 Distribusi Tingkat Nyeri Pasca Operasi Radang Usus Buntu dengan Laparoskopi Hari Pertama hingga Hari Ketiga

\begin{tabular}{|c|c|c|c|c|c|c|c|c|c|c|}
\hline \multirow{2}{*}{$\begin{array}{l}\text { Evaluasi Hari Pasca } \\
\text { Operasi }\end{array}$} & \multicolumn{2}{|c|}{ Tidak (0) } & \multicolumn{2}{|c|}{ Nyeri Ringan (1-3) } & \multicolumn{2}{|c|}{ Nyeri Sedang (4-6) } & \multicolumn{2}{|c|}{ Nyeri Berat (7-10) } & \multicolumn{2}{|c|}{ Total } \\
\hline & (N) & (\%) & (N) & (\%) & (N) & (\%) & (N) & $(\%)$ & (N) & $(\%)$ \\
\hline Hari Pertama & 3 & 50,0 & 3 & 50.0 & - & - & - & - & 6 & 100 \\
\hline Hari Kedua & 4 & 66,7 & 2 & 33.3 & - & - & - & - & 6 & 100 \\
\hline Hari Ketiga & 5 & 83,3 & 1 & 16.7 & - & - & - & - & 6 & 100 \\
\hline
\end{tabular}

Tabel 1.5 Distribusi Tingkat Nyeri Pasca Operasi Radang Usus Buntu dengan Bedah Terbuka Berdasarkan Jenis Kelamin Hari Pertama hingga Hari Ketiga

\begin{tabular}{lccccc}
\hline & \multicolumn{3}{c}{ Nyeri } & \multirow{2}{*}{ Total } \\
\cline { 2 - 4 } Jenis Kelamin & Tidak (N, \%) & Ringan (N, \%) & Sedang (N, \%) & Berat (N, \%) & \\
\hline Hari Pertama & & & & & \\
$\quad$ Laki-laki & $0(0 \%)$ & $18(66.7 \%)$ & $9(33.3 \%)$ & $0(0 \%)$ & $27(100 \%)$ \\
$\quad$ Perempuan & $0(0 \%)$ & $15(88.2 \%)$ & $2(11.8 \%)$ & $0(0 \%)$ & $17(100 \%)$ \\
Total & $0(0 \%)$ & $33(75.0 \%)$ & $11(25.0 \%)$ & $0(0 \%)$ & $44(100 \%)$ \\
Hari Kedua & & & & $27(100 \%)$ \\
$\quad$ Laki-laki & $1(3.7 \%)$ & $21(77.8 \%)$ & $5(18.5 \%)$ & $0(0 \%)$ & $17(100 \%)$ \\
$\quad$ Perempuan & $0(0 \%)$ & $17(100 \%)$ & $0(0 \%)$ & $0(0 \%)$ & $44(100 \%)$ \\
Total & $1(2.3 \%)$ & $38(86.4 \%)$ & $5(11.4 \%)$ & $0(0 \%)$ & $27(100 \%)$ \\
Hari Ketiga & & & & $17(100 \%)$ \\
$\quad$ Laki-laki & $4(14.8 \%)$ & $22(81.5 \%)$ & $1(3.7 \%)$ & $0(0 \%)$ & $0(0 \%)$ \\
$\quad$ Perempuan & $0(0 \%)$ & $17(100 \%)$ & $0(0 \%)$ & $0(0 \%)$ & $44(100 \%)$ \\
Total & $4(9.1 \%)$ & $39(88.6 \%)$ & $1(2.3 \%)$ &
\end{tabular}

\section{DISKUSI}

Toxonomi Comitte of The International Assocation memaparkan bahwa nyeri pasca operasi sebagai sensori yang tidak menyenangkan dan pengalaman emosi yang berhubungan dengan kerusakan jaringan potensial atau nyata yang menggambarkan terminology suatu kerusakan.

Tingkatan intensitas nyeri juga banyak dipengaruhi oleh faktor lainnya seperti teknik operasi, jenis kelamin dan usia. ${ }^{7}$ Berdasarkan jenis kelamin bahwa laki-laki dan perempuan tidak memiliki perbedaan secara signifikan mengenai respon mereka terhadap nyeri. Masih diragukan bahwa jenis kelamin merupakan faktor yang berdiri sendiri dalam persepsi nyari. Penelitian yang dilakukan Burn, dkk (1989) dikutip dari Cindrawati
Langanawa (2013) kebutuhan narkotik pasca operasi pada wanita lebih banyak dibandingkan dengan pria. Pada penelitian yang dilakukan oleh pederita radang usus buntu memang lebih di dominasi oleh laki-laki daripada wanita sesuai dengan data yang diperoleh dari penelitinan sebesar 27 orang $61.4 \%$ laki-laki dan 17 orang $38.6 \%$ perempuan dari 44 pasien pasca operasi radang usus buntu dengan bedah terbuka, sedangkan terdata 5 orang 83.3\% laki-laki dan 1 orang $16.7 \%$ perempuan dari 6 pasien pasca operasi radang usus buntu dengan laparoskopi. Dari evalusi tingkatan nyeri dari hari pertam hingga hari ketiga didapatkan bahwa nyeri ringan mendominasi pada laki-laki maupun perempuan pada teknik bedah terbuka, sedangkan 
Tabel 1.6 Distribusi Tingkat Nyeri Pasca Operasi Radang Usus Buntu dengan Laparoskopi berdasarkan Janis kelamin Hari Pertama hingga Hari Ketiga

\begin{tabular}{|c|c|c|c|c|c|}
\hline \multirow[b]{2}{*}{ Jenis Kelamin } & \multicolumn{4}{|c|}{ Nyeri } & \multirow[b]{2}{*}{ Total } \\
\hline & Tidak (N, \%) & Ringan (N, \%) & Sedang (N, \%) & Berat $(\mathrm{N}, \%)$ & \\
\hline \multicolumn{6}{|l|}{ Hari Pertama } \\
\hline Laki-laki & $2(40.0 \%)$ & $3(60.0 \%)$ & $0(0 \%)$ & $0(0 \%)$ & $5(100 \%)$ \\
\hline Perempuan & $1(100 \%)$ & $0(0 \%)$ & $0(0 \%)$ & $0(0 \%)$ & $1(100 \%)$ \\
\hline Total & $3(50.0 \%)$ & $3(50.0 \%)$ & $0(0 \%)$ & $0(0 \%)$ & $6(100 \%)$ \\
\hline \multicolumn{6}{|l|}{ Hari Kedua } \\
\hline Laki-laki & $4(80.0 \%)$ & $1(20.0 \%)$ & $0(0 \%)$ & $0(0 \%)$ & $5(100 \%)$ \\
\hline Perempuan & $0(0 \%)$ & $1(100 \%)$ & $0(0 \%)$ & $0(0 \%)$ & $1(100 \%)$ \\
\hline Total & $4(66.7 \%)$ & $2(33.3 \%)$ & $0(0 \%)$ & $0(0 \%)$ & $6(100 \%)$ \\
\hline \multicolumn{6}{|l|}{ Hari Ketiga } \\
\hline Laki-laki & $4(80.0 \%)$ & $1(20.0 \%)$ & $0(0 \%)$ & $0(0 \%)$ & $5(100 \%)$ \\
\hline Perempuan & $1(100 \%)$ & $0(0 \%)$ & $0(0 \%)$ & $0(0 \%)$ & $1(100 \%)$ \\
\hline Total & $5(83.3 \%)$ & $1(16.7 \%)$ & $0(0 \%)$ & $0(0 \%)$ & $6(100 \%)$ \\
\hline
\end{tabular}

Tabel 1.7 Distribusi Tingkat Nyeri Pasca Operasi Radang Usus Buntu dengan Bedah Terbuka Berdasarkan Usia Hari Pertama hingga Hari Ketiga

\begin{tabular}{|c|c|c|c|c|c|}
\hline \multirow[b]{2}{*}{ Usia } & \multicolumn{4}{|c|}{ Nyeri } & \multirow[b]{2}{*}{ Total } \\
\hline & Tidak $(\mathbf{N}, \%)$ & Ringan $(\mathbf{N}, \%)$ & Sedang $(\mathbf{N}, \%)$ & Berat $(\mathrm{N}, \%)$ & \\
\hline \multicolumn{6}{|l|}{ Hari Pertama } \\
\hline 13-20 tahun & $0(0 \%)$ & $10(62.5 \%)$ & $6(0 \%)$ & $0(0 \%)$ & $2(100 \%)$ \\
\hline 21-30 tahun & $0(0 \%)$ & $6(60.0 \%)$ & $4(33.3 \%)$ & $0(0 \%)$ & $9(100 \%)$ \\
\hline 31-40 tahun & $0(0 \%)$ & $7(100 \%)$ & $0(0 \%)$ & $0(0 \%)$ & $21(100 \%)$ \\
\hline 41-50 tahun & $0(0 \%)$ & $6(100 \%)$ & $0(0 \%)$ & $0(0 \%)$ & $12(100 \%)$ \\
\hline 51-60 tahun & $0(0 \%)$ & $4(80.0 \%)$ & $1(20.0 \%)$ & $0(0 \%)$ & $2(100 \%)$ \\
\hline Total & $0(0 \%)$ & $33(75.0 \%)$ & $11(25.0 \%)$ & $0(0 \%)$ & $44(100 \%)$ \\
\hline \multicolumn{6}{|l|}{ Hari Kedua } \\
\hline 13-20 tahun & $0(0 \%)$ & $14(62.5 \%)$ & $2(12.5 \%)$ & $0(0 \%)$ & $16(100 \%)$ \\
\hline 21-30 tahun & $0(0 \%)$ & $9(90.0 \%)$ & $1(10.0 \%)$ & $0(0 \%)$ & $10(100 \%)$ \\
\hline 31-40 tahun & $1(14.3 \%)$ & $5(71.4 \%)$ & $1(14.3 \%)$ & $0(0 \%)$ & $7(100 \%)$ \\
\hline 41-50 tahun & $0(0 \%)$ & $6(100 \%)$ & $0(0 \%)$ & $0(0 \%)$ & $6(100 \%)$ \\
\hline 51-60 tahun & $0(0 \%)$ & $4(80.0 \%)$ & $1(20.0 \%)$ & $0(0 \%)$ & $5(100 \%)$ \\
\hline Total & $1(2.3 \%)$ & $38(86.4 \%)$ & $5(11.4 \%)$ & $0(0 \%)$ & $44(100 \%)$ \\
\hline \multicolumn{6}{|l|}{ Hari Ketiga } \\
\hline 13-20 tahun & $1(6.3 \%)$ & $15(93.8 \%)$ & $0(0 \%)$ & $0(0 \%)$ & $16(100 \%)$ \\
\hline 21-30 tahun & $0(0 \%)$ & $10(100 \%)$ & $0(0 \%)$ & $0(0 \%)$ & $10(100 \%)$ \\
\hline 31-40 tahun & $0(0 \%)$ & $7(100 \%)$ & $0(0 \%)$ & $0(0 \%)$ & $7(100 \%)$ \\
\hline 41-50 tahun & $2(33.3 \%)$ & $4(66.7 \%)$ & $0(0 \%)$ & $0(0 \%)$ & $6(100 \%)$ \\
\hline 51-60 tahun & $1(20.0 \%)$ & $3(60.0 \%)$ & $1(20.0 \%)$ & $0(0 \%)$ & $5(100 \%)$ \\
\hline Total & $4(9.1 \%)$ & $39(88.6 \%)$ & $1(2.3 \%)$ & $0(0 \%)$ & $44(100 \%)$ \\
\hline
\end{tabular}

pada teknik dengan laparoskopi tidak nyeri lebih mendominasi pada laki-laki maupun perempuan

Menurut Potter dan Parry (2011) usia merupakan salah satu variable penting yanh dapat mempengaruhi nyeri, terutama pada anak dan dewasa.
Perbedaan perkembangan anak dan orang dewasa dapat memengaruhi bagaimana kedua kelompok usia ini bereaksi terhadap tingkatan nyeri yang dirasakan. Anak-anak lebih merasa kesulitan untuk memahami nyeri yang dirasakan, sedangkan orang dewasa 
Tabel 1.8 Distribusi Tingkat Nyeri Pasca Operasi Radang Usus Buntu dengan Bedah Terbuka Berdasarkan Usia Hari Pertama hingga Hari Ketiga

\begin{tabular}{|c|c|c|c|c|c|}
\hline \multirow[b]{2}{*}{ Usia } & \multicolumn{4}{|c|}{ Nyeri } & \multirow[b]{2}{*}{ Total } \\
\hline & Tidak $(\mathbf{N}, \%)$ & Ringan $(\mathbf{N}, \%)$ & Sedang $(\mathbf{N}, \%)$ & Berat $(\mathrm{N}, \%)$ & \\
\hline \multicolumn{6}{|l|}{ Hari Pertama } \\
\hline 13-20 tahun & $2(50.0 \%)$ & $2(50,0 \%)$ & $0(0 \%)$ & $0(0 \%)$ & $4(100 \%)$ \\
\hline 21-30 tahun & $0(0 \%)$ & $0(0 \%)$ & $0(0 \%)$ & $0(0 \%)$ & $0(0 \%)$ \\
\hline 31-40 tahun & $1(50.0 \%)$ & $1(50,0 \%)$ & $0(0 \%)$ & $0(0 \%)$ & $2(100 \%)$ \\
\hline 41-50 tahun & $0(0 \%)$ & $0(0 \%)$ & $0(0 \%)$ & $0(0 \%)$ & $0(0 \%)$ \\
\hline 51-60 tahun & $0(0 \%)$ & $0(0 \%)$ & $0(0 \%)$ & $0(0 \%)$ & $0(0 \%)$ \\
\hline Total & $3(50.0 \%)$ & $3(50.0 \%)$ & $0(0 \%)$ & $0(0 \%)$ & $6(100 \%)$ \\
\hline \multicolumn{6}{|l|}{ Hari Kedua } \\
\hline 13-20 tahun & $3(75.0 \%)$ & $1(25.0 \%)$ & $0(0 \%)$ & $0(0 \%)$ & $4(100 \%)$ \\
\hline 21-30 tahun & $0(0 \%)$ & $0(0 \%)$ & $0(0 \%)$ & $0(0 \%)$ & $0(0 \%)$ \\
\hline 31-40 tahun & $1(50.0 \%)$ & $1(50.0 \%)$ & $0(0 \%)$ & $0(0 \%)$ & $2(100 \%)$ \\
\hline 41-50 tahun & $0(0 \%)$ & $0(0 \%)$ & $0(0 \%)$ & $0(0 \%)$ & $0(0 \%)$ \\
\hline 51-60 tahun & $0(0 \%)$ & $0(0 \%)$ & $0(0 \%)$ & $0(0 \%)$ & $0(0 \%)$ \\
\hline Total & $4(66.7 \%)$ & $2(33.3 \%)$ & $0(0 \%)$ & $0(0 \%)$ & $6(100 \%)$ \\
\hline \multicolumn{6}{|l|}{ Hari Ketiga } \\
\hline 13-20 tahun & $4(100 \%)$ & $0(0 \%)$ & $0(0 \%)$ & $0(0 \%)$ & $4(100 \%)$ \\
\hline 21-30 tahun & $0(0 \%)$ & $0(0 \%)$ & $0(0 \%)$ & $0(0 \%)$ & $0(0 \%)$ \\
\hline 31-40 tahun & $1(50.0 \%)$ & $1(50.0 \%)$ & $0(0 \%)$ & $0(0 \%)$ & $2(100 \%)$ \\
\hline 41-50 tahun & $0(0 \%)$ & $0(0 \%)$ & $0(0 \%)$ & $0(0 \%)$ & $0(0 \%)$ \\
\hline 51-60 tahun & $0(0 \%)$ & $0(0 \%)$ & $0(0 \%)$ & $0(0 \%)$ & $0(0 \%)$ \\
\hline Total & $5(83.3 \%)$ & $1(16.7 \%)$ & $0(0 \%)$ & $0(0 \%)$ & $6(100 \%)$ \\
\hline
\end{tabular}

terkadang lebih dapat mengemukakan tingkat nyeri yang dirasakan. ${ }^{7}$ Berdasarkan hasil penelitian didapatkan bahwa pasein pasca operasi radang usus buntu dengan teknik bedah terbuka di dominasi oleh nyeri ringan dengan usia berda di rentang 13- 20 tahun, sedangkan pada teknik laparoskopi didominasi oleh tidak nyeri dengan rentang usia 13-20 tahun

Jenis operasi yang dilakukan merupakan klasifikasi tindadakan medis bedah yang berdasarkan waktu, alat, jenis anestesi, teknik operasi, luasnya insisi/sayatan, dan resiko yang dialami, hal ini meliputi operasi kecil, sedang, besar, khusus. ${ }^{7}$ Jenis operasi yang dilakukan juga berpengaruh terhadap intesitas nyeri pasca operasi, ${ }^{8}$ karena jenis operasi menentukan luasnya manipulasi pembedahan serta kerusakan jaringan yang akan terjadi. Lokasi dan ukuran insisi adalah salah satu faktor yang juga mempengaruhi intensitas nyeri pasca operasi, insisi/sayatan yang panjang akan dirasakan lebih nyeri dibandikan dengan insisi/sayatan yang kecil atau pendek. ${ }^{8}$

Tingkat intensitas nyeri pada penelitian ini didasarkan pada penelian VAS (Visual Analog Scale) pada hari 1, hari 2 dan hari 3 pasca operasi radang usus buntu baik dengan bedah terbuka ataupun laparoskopi. Menurut Williamson dan Hoggart
(2005), VAS merupakan teknik pengukuran nyeri yang reliable, valid, dan sensitive baik untuk anakanak taupun dewasa. Pengukuran Vas cepat, mudah, dan umum digunakan dalam penelitoan maupun sub klinis. Skor VAS merupakan perasaan subyektif pasien yang dianalogkan ke dalam angak 1-10. ${ }^{7}$

Pada penelitian ini jenis operasi terbagi atas bedah terbuka dan laparoskopi, pada operasi radang usus buntu dengan bedah terbuka dimana pada teknik ini sekitar 2-4 inci luas insisi/ sayatan pada abdomen kanan bawah. ${ }^{9}$ Penelitian yang dilakukan dengan jumlah sample 44 orang terdata bahwa hari pertama terdapat sebanyak $75 \%$ nyeri ringan dan $25 \%$ nyeri sedang, pada hari kedua $2.3 \%$ tidak nyeri, $86.4 \%$ nyeri ringan dan $11.4 \%$ nyeri sedang, hari ketiga terdata $9.1 \%$ tidak nyeri, $88.6 \%$ nyeri ringan, dan $2.3 \%$ nyeri sedang. Sedangkan pada operasi radang usus buntu dengan teknik laparoskopi dimana pada teknik invasive ini hanya dibuat 1-3 sayatan kecil untuk memasukan port/nozzle. Data penelitian dengan jumlah sampel 6 orang terdapat bahwa pada hari pertama sebanyak $50 \%$ tidak nyeri dan $50 \%$ nyeri sedang, hari kedua $66.7 \%$ tidak nyeri dan $33.3 \%$ nyeri sedang, dan hari ketiga $83.3 \%$ tidak nyeri dan $16.7 \%$ nyeri ringan. 


\section{SIMPULAN}

Berdasarkan hasil penelitian ini, evaluasi tingkat nyeri pasien pasca operasi radang usus buntu dengan bedah terbuka dan laparoskopi di Rumah Sakit Umum Pusat Sanglah Denpasar tahun 20142016, yang dievalusi selama tiga hari pasca operasi yakni didominasi oleh nyeri ringan pada bedah terbuka sedangkan laparoskopi didominasi oleh tanpa nyeri. Karakteristik data sampel terbanyak tingkat nyeri pasien pasca operasi radang usus buntu dengan bedah terbuka dan laparoskopi adalah sebagai berikut: jenis kelamin laki-laki, usia 13-20 tahun.

\section{DAFTAR PUSTAKA}

1. Dorland W.A.N. 2000. Dorland's IllustRatingd Medical Dictionary. 29th ed. Terjemahan: Huriawati Hartanto. Jakarta: Penerbit Buku Kedokteran EGC. p.142.

2. Sjamsuhidajat, R. dan De Jong W. 2005. Buku Ajar Ilmu Bedah. Jakarta: EGC
3. Eylin. Karakteristik Pasien dan Diagnosis Histologi pada Kasus Radang Usus Buntu Berdasarkan Data Registasi di Departemen Patologi Anatomi Fakultas Kedokteran Universitas Indonesia Rumah Sakit Umum Pusat Nasional Cipto Mangunkusumo pada Tahun 2003-2007; 2009.

4. Breivik H, Borchgrenvink PC, Allen SM, dkk. Assessment of pain. Br J Anaesth 2008; 101 (1): 17-24

5. Brunner Suddarth. 2005. Keperawatan Medikal Bedah. edisi 8.Jakarta : EGC

6. Hawker GA, Mian S, Kendzerka T, dan French M. Measure of Adult Pain. Arthritis Care and Research 2011; 63: 240-52

7. Cindrawati Langanawa. Gambaran Tingkat Nyeri Pada Pasien Post Operasi Di Ruangan Bedah RSUD Prof. Dr. Hi. Aloei Saboe; 2013.

8. Rahma, M dan Beattie, J. Managing Postoperative Pain Through Giving Patient Control; 2005.

9. American Collage Surgeon. Open Surgery and Laparoscopy in appendicitis; 2014. https://www.journal.elsevier.com/ journal-of-the-american-collage-of-surgeons. [Diakses pada tanggal 13 Oktober 2017]

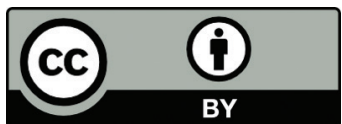

This work is licensed under a Creative Commons Attribution 